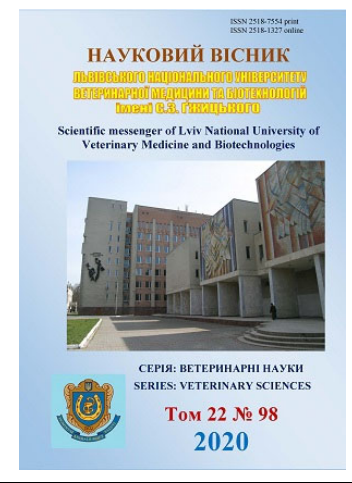

\author{
Науковий вісник Дьвівського національного університету \\ ветеринарної медицини та біотехнологій імені С.3. Гжицького. \\ Серія: Ветеринарні науки \\ Scientific Messenger of Lviv National University \\ of Veterinary Medicine and Biotechnologies. \\ Series: Veterinary sciences
}

UDC 619:616-092:591.471.36:636.4

\title{
Efficiency of complex pig therapy with pathology of the distal department of the limbs
}

\author{
B. P. Kyrychko, V. V. Semirenko \\ Poltava State Agrarian Academy, Poltava, Ukraine
}

Article info

Received 02.03.2020

Received in revised form 06.04 .2020

Accepted 07.04.2020

Poltava State Agrarian Academy Skovorody Str., 1/3, Poltava, 36003, Ukraine

Tel.: +38-096-965-42-53

E-mail:mdsemvet@ukr.net
Kyrychko, B. P., \& Semirenko, V. V. (2020). Efficiency of complex pig therapy with pathology of the distal department of the limbs. Scientific Messenger of Lviv National University of Veterinary Medicine and Biotechnologies. Series: Veterinary sciences, 22(98), 3-8. doi: 10.32718/nvlvet9801

Studies have been conducted to establish the dynamics of the course of treatment of purulentinflammatory process of distal limb in pigs. The treatment algorithm was presented by two schemes: classic (I - experimental screw) and experimental (II - experimental group). Among the morphological parameters investigated: hemoglobin level, erythrocyte sedimentation rate (ESR), hematocrit, leukograms, total erythrocytes and leukocytes in the blood. To determine the immunobiological activity of the body of sick pigs, serum T: lymphocytes (CD2, CD3), T-helper cells (CD4), T-suppressors/killers (CD8), IRI (T-help/T-sup.), NK cells (CD16), B-lymphocytes (CD22), immunoglobulins $A, M, G, C E C$ and phagocytic index. Research objectives - determining the effectiveness of treatment regimens algorithm for morphological and immunological composition of the blood in different forms of lymphoma disease distal extremities in pigs. Manifestation effector function was observed a decrease in lymphocytes, proliferation and differentiation of corresponding antibodies of the immune system of pigs. Inhibition of regulatory function in the inflammatory process reduces the mechanisms of formation of biologically active compounds "chemotaxis factor", "transfer factor", "phagocytosis factor", migration of neutrophils and macrophages. The decrease in the concentration of NK cells in 2 times, with the pathology open wound, indicates a decrease in the process of opsonization (antibody-dependent cellular cytotoxicity) due to the lack of immune response to pathogens in the inflammatory cell. In abscesses, purulent pododermatitis and laminitis, NK cells decrease 1.5 times with the indirect manifestation of specific cytotoxic cells (B-lymphocytes, macrophages). It is determined that the drug "Trifuzol 1\%" activates effector and reparative function of specific components of immune activity (T and B lymphocytes, population of $T$ cells, $N K$ cells). The results of these studies in the article thoroughly show the dynamics of changes in morphological and immunological status of pigs for diseases of the musculoskeletal system of the distal extremity. The results will facilitate the work of veterinary practitioners in the treatment of nosological forms of distal limb diseases in pigs.

Key words: pigs, lameness, trifuzole, T-cells, bandage.

\section{Ефективність комплексної терапії свиней з патологією дистального відділу кінцівок}

\author{
Б. П. Киричко, В. В. Семіренко
}

Полтавська державна аграрна академія, м. Полтава, Украӥна

\footnotetext{
Дослідження проводились для встановлення динаміки перебігу лікування гнійно-запального процесу дистального відділу кінцівок у свиней. Алгоритм лікування був представлений двома схемами: класична (I - дослідна група) та експериментальна (II - дослідна група). Серед морфологічних показників досліджували: рівень гемоглобіну, ШОЕ, гематокрит, показники лейкограми, загальну кількість еритрочитів і лейкоцитів в крові. Для визначення імунобіологічної активності організму хворих свиней, досліджували в сироватці: Т-лімфоцити (СД2, СД3), Т-хелпери (СД4), Т-супресори/кілери (СД8), IPI (Т-хелn./Т-супр.), NK-клітини (СД16), Влімфочити (СД22), імуноглобуліни А, М, G, ЦІК і фагоџитарний індекс. Завдання дослідження - визначення ефективності алгори-
} 
тму схем лікування за морфологічним та імунологічним складом крові, при різних нозологічних формах хвороб дистального відділу кінцівок у свиней. Прояв ефекторної функції простежується при зменшенні В-лімфоцитів, проліферації і диференціюванні відповідних антитіл імунної системи організму свиней. Гальмування регуляторної функції при запальному процесі знижує механізми утворення біологічно активних сполук “фактору хемотаксису”, “фактору переносу”, “фактору фагоцитозу”, міграції нейтрофілів та макрофагів. Зменшення концентраиії NK-клітин у 2 рази, при патологї відкрита рана, свідчить про зниження процесу опсонізіції (антитілозалежна клітинна циитотоксичність) через недостатність імунної відповіді на збудники в осередку запалення. При абсиесі, гнійному пододерматиті та ламініті спостерігається зниження NК-клітин у 1,5 рази з опосередкованим проявом дії специфічних цитотоксичних клітин (В-лімфоцити, макрофаги). Визначено, цчо препарат “Трифузол 1 \%” активує ефекторну $i$ репаративну функиію специфічних компонентів імунної активності (T- $i$ B-лімфоцити, популяція T-клітин, NK-клітини). Результати наведених досліджень у статті грунтовно показують динамку зміни морфологічного та імунологічного стану свиней за хвороб опорно-рухового апарату дистального відділу кінцівок. Опрацьовані результати полегшать роботу практикуючим ветеринарним лікарям при лікуванні нозологічних форм хвороб дистального відділу кінцівок у свиней.

Ключові слова: кульгавість, трифузол, Т-клітини, бандаж-пов'язка.

\section{Вступ}

Вивчаючи етіологію та патогенез нозологічних форм хвороб дистального відділу кінцівок у свиней, регулярно ведеться розробка алгоритму ефективних схем терапевтичного лікування. В терапії болю i запалення при порушеннях опорно-рухової системи, найбільш широкого використання отримали нестероїдні протизапальні засоби (НП33) (Рopov, 2013).

M. C. Garcia et al. (1980), M. J. Harris et al (2006), E. O. Nielsen et al. (2001) стверджують, що при кульгавості інфекційної етіології показана терапія 3 використанням антибактеріальних препаратів. У разі випадку клінічних ознак м'язової слабкості, антибактеріальну терапію доповнюють кортикостероїдними засобами. Встановлено, що введення кортикостероїдів у період лактації негативно впливає на молочність свиноматок і знижує темпи росту поросят-сисунів (Mullan et al., 2009).

Враховуючи ризик стійкості мікроорганізмів до антибіотиків, слід проводити відповідний тест на чутливість збудника до протимікробних препаратів. Частіше в лікувальній практиці опорно-рухового апарату у свиней застосовується антибіотик пеніцилін i його аналоги. Завдяки швидкому розподілу антибіотику в тканинах кісток i суглобів та пригнічення інфекції в глибоких структурах копитець, C. Rowles, 2001; R. P. Cowart, S. W. Casteel, 2002 рекомендують вводити високу концентрацію лінкоміцину при ламініті і артриті.

В дослідженнях іноземних вчених (Main et al., 2000; Dewey et al., 2006; Mullan et al., 2009; Quinn et al., 2013; Karriker, 2013) висвітлені проблеми опорнорухового апарату, що пов'язані з неврологічними розладами, порушенням механічної структури, метаболічними та інфекційними захворюваннями, травматичними ураженнями копитець або кінцівки (Madsen, 2008). Кульгавість виникає через неправильну конформацію тіла свині, пошкодженнях анатомічних структур копитець, порушень функціонування опорно-рухового апарату та нервової системи. Методи діагностики, лікування i профілактики хірургічних хвороб опорно-рухового апарату кінцівок у свиней, потребують ретельного вивчення й розробки сучасних підходів (Wells, 1984; Smith, 1988; Jensen et al., 2010; Rowles, 2001).

\section{Матеріал і методи досліджень}

Лікування свиней $з$ хірургічними формами хвороб кінцівок проводили в господарстві ТОВ “Смак Миргородщина" (с. Руда, Миргородського району, Полтавської обл). В дослідженні використовували свиноматки (1,5-2 роки) і ремонтні свині, порід велика білка та ландрас. Хворих свиней поділили на дві групи відповідно до терапевтичних схем лікування: I - дослідна група “класична”, II - дослідна група “експеримент”, що наведені у таблиці 1. Згідно нозологічних форм хвороб кінцівок, були сформовані підгрупи по 10 свиней з відповідними патологіями: відкрита рана, абсцес, ламініт, асептичний та гнійний пододерматит дистального відділу кінцівок. Для контрольної групи відбирали кров від здорових свиней у кількості 12 тварин.

\section{Таблиця 1}

Терапевтичні схеми лікування хвороб дистального відділу кінцівок у свиней

\begin{tabular}{|c|c|c|}
\hline Вид терапії & I - дослідна група “класична” & II - дослідна група “експеримент” \\
\hline Антибіотикотерапія & $\begin{array}{l}\text { Цефтіонель } 50 \text { (в/м } 11 \text { мл/16 кг) } \\
\text { протягом } 3 \text { днів }\end{array}$ & Альфаміцин (в/м 1 мл/ 25 кг) \\
\hline Протизапальна, імуностимулююча & Аініл (в/м 3 мл/ 100 кг) & “Трифузол 1 \%” (в/м 5 мл, 5 днів) \\
\hline Обробка та зрошення & $\begin{array}{l}\text { розчин } \mathrm{H}_{2} \mathrm{O}_{2} \quad(3 \quad \%), \quad \mathrm{KMnO}_{4} \\
(1: 1000), \text { фракція АСД-2 }(20 \%)\end{array}$ & р-н $\mathrm{H}_{2} \mathrm{O}_{2}$ (3 \%), p-н хлорофіліпту (1:3) \\
\hline Компреси, бинтові пов'язки & $\begin{array}{l}\text { мазь “Левомеколь”, “Стрептоміци- } \\
\text { нова”, іхтіолова мазь, лінімент } \\
\text { бальзамічний по Вишневському, 3- } \\
5 \text { днів }\end{array}$ & $\begin{array}{l}\text { крем-гель “Alezan" з АСД і мірамістином, } \\
\text { компрес із Бішофіту (1:1), 4-7 днів, компрес із } \\
\text { пробіотиком - засіб для гігієни копитець } \\
\left.\text { Sviteco-СFC (1 мл/1л теплої води, } t=25-35^{\circ} \mathrm{C}\right) \text {, } \\
\text { 7-10 днів }\end{array}$ \\
\hline Тип фіксації лікарських засобів & $\begin{array}{l}\text { спеціальна стрічка для копитець } \\
\text { або поліетилен із чохлом матерії }\end{array}$ & $\begin{array}{l}\text { бандаж-пов’язка для копитець } \\
\text { (патент №113537) }\end{array}$ \\
\hline
\end{tabular}


Для покращення гомеостазу та активації обмінних процесів, свиням в обох дослідних групах вводили препарат "Катозал" в/м 10 мл, двічі 3 інтервалом 5 днів. Також застосовували препаратом "Тетравіт" (в/м 5 мл, двічі 3 інтервалом 7-10 днів).

Кров від дослідних груп свиней відбирали на 1день, 8 і 16 день лікування. Лабораторні дослідження по морфології крові свиней, проводилися в Миргородській районній державній лабораторії ветеринарної медицини. Серед морфологічних показників крові свиней визначали: концентрація гемоглобіну - колориметричним методом в гемометрі Салі, ШОЕ - метод Панченкова, кількість еритроцитів і лейкоцитів пробірковий метод М. П. П'ятницького, гематокрит метод Й. Тодорова, а розгорнуту лейкограму - трипольним методом, (фарбування за РомановськимГімзою). Імунологічні результати (СД2, СД3, СД4, СД8, СД16, СД22, імуноглобуліни А, М, G, ЦІК і фагоцитарний індекс) отримували в медичній установі. Показники лабораторних досліджень статистично обробляли 3 використанням параметру t-критерія Стьюдента в програмі “Excel-2010”.

\section{Результати та їх обговорення}

Відповідні зміни морфологічних показників крові чітко простежуються за різних нозологічних форм гнійно-запальних процесів дистального відділу кінцівок у свиней. Дослідження показали, що у хворих свиней із патологіями кінцівок спостерігали підвищення кількості лейкоцитів і швидкості осідання еритроцитів (ШОЕ). В лейкограмі відмічали зрушення ядра нейтрофілів вліво зі зменшення загальної кількості лімфоцитів (субпопуляції Т і В клітин). Внаслідок стресу і больової реакції, що обумовлена механічним пошкодженням структур копитець, в крові хворих свиней зросла кількість еозинофілів.

Методи лікування хворих свиней із патологією відкрита рана мали однаковий терапевтичний ефект, зокрема у свиней I групи дослідження зросла кількість гемоглобіну в крові, порівняно дослідної групи свиней (рис. 1, а).

Протягом періоду лікування у II дослідній групі було відмічене прискорення перебігу стадій загоєння рани, порівняно I групи дослідження на 3-5 днів за рахунок пов'язки-бандаж, що подовжувала терапевтичний ефект лікарських засобів.

При аналізі морфологічного складу крові дослідних груп, спостерігалась чітка закономірність зростання кількості показників гематограми: гемоглобін, ШОЕ, гематокрит та еритроцитів, по відношенню до періоду лікування. У дослідних групах зростала кількість лейкоцитів із відновленням показників лейкограми, зокрема збільшення сегментоядерних нейтрофілів і зменшення інших компонентів лейкоформули.

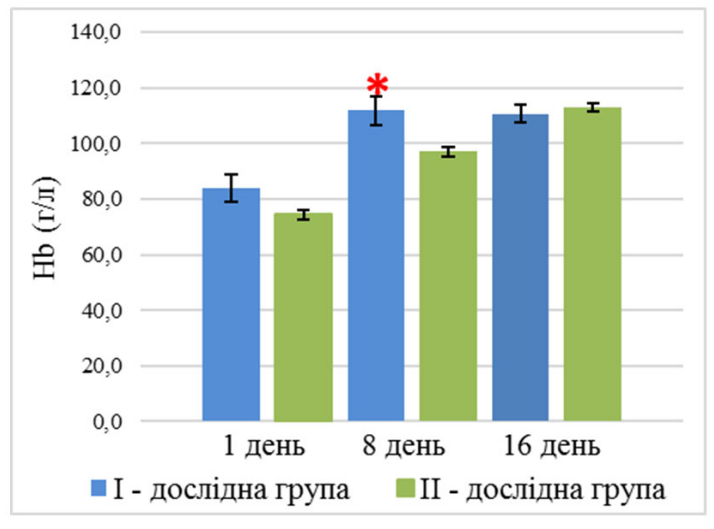

a
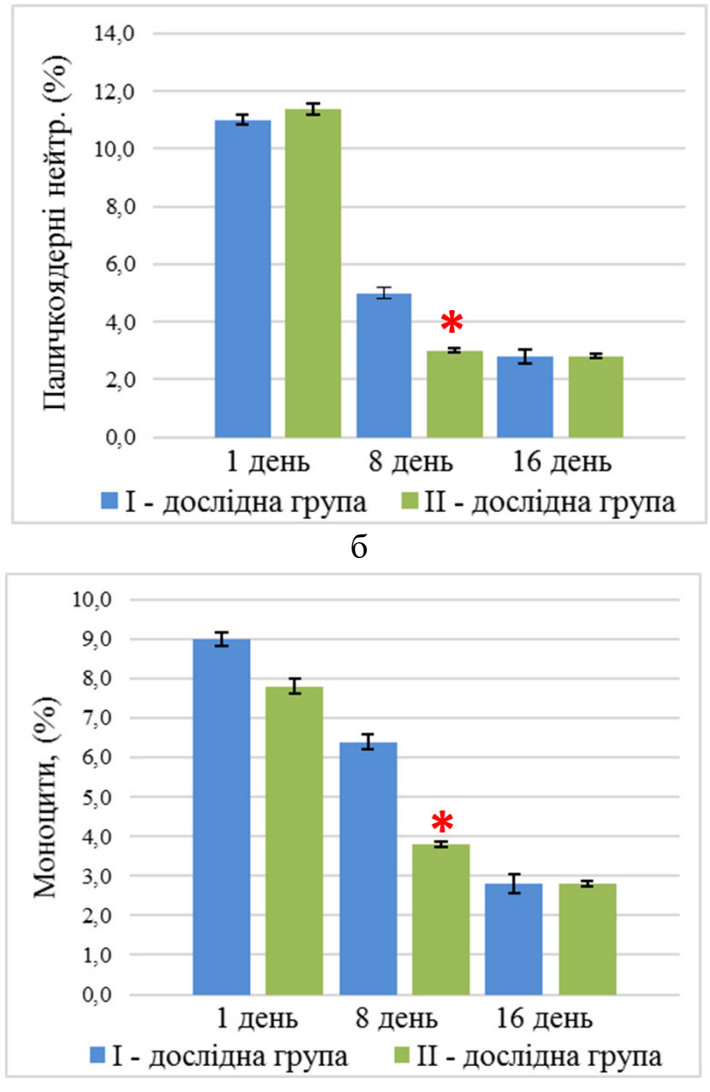

B

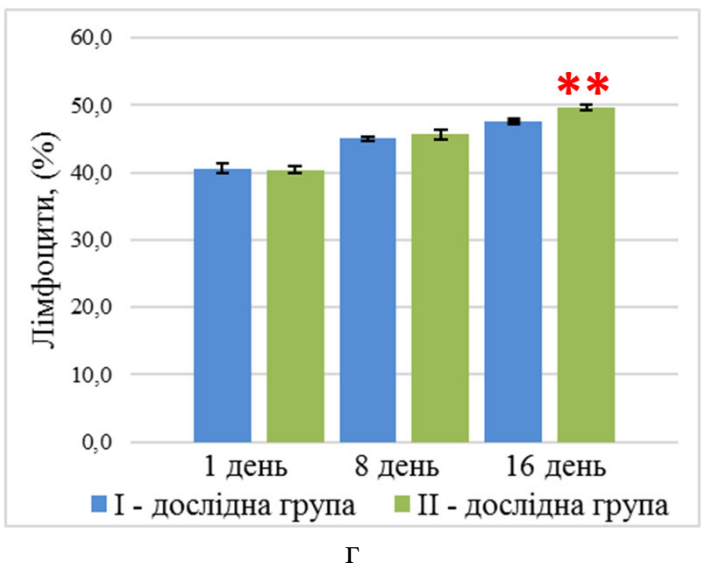




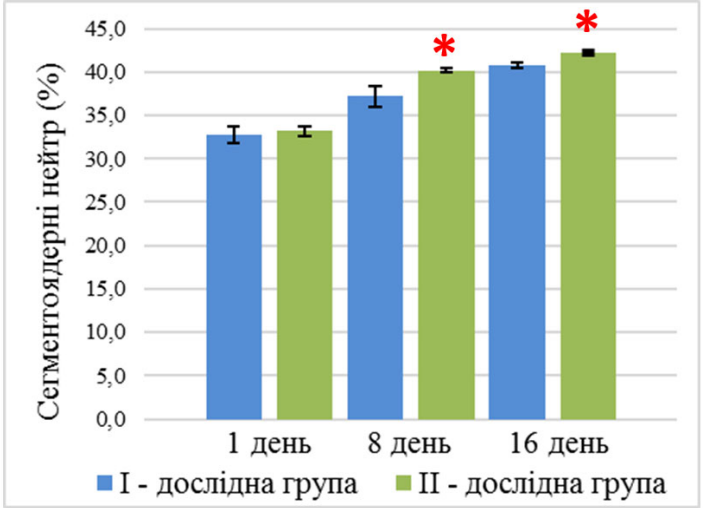

Д



Рис. 1. Результати морфологічного складу крові хворих свиней з гнійно-запальними процесами дистального відділу кінцівок в період лікування до повного одужання: а - відкрита рана; б, в - абсцес; г - асепти-

чний пододерматит; д, е - гнійний пододерматит

Примітка: * - $\mathrm{P}<0,05, * *-\mathrm{P}<0,01$ щодо показників днів лікування

За даними рис. $1(\sigma$, в) у II дослідній групі свиней при патології абсцес в ділянці дистального відділу кінцівок, відмічене суттєве зниження паличкоядерних нейтрофілів та моноцитів, що свідчить про загоєння запального процесу. У II дослідній групі свиней із патологією - асептичний пододерматит спостерігається вірогідно (Р < 0,01) збільшення кількості лімфоцитів до $49,6 \pm 0,43 \%$ проти I дослідної групи (рис. 1, г). Показники гематограми не мають вірогідних змін по відношенню до схем лікування хворих свиней із асептичним пододерматитом.

При гнійному пододерматиті у свиней II дослідної групи на 8 день лікування відмічено вірогідне $(\mathrm{P}<0,01)$ зменшення кількості паличкоядерних нейтрофілів до $3,2 \pm 0,64 \%$ та моноцитів до $3,8 \pm 1,07 \%$ $(\mathrm{P}<0,05)$ порівняно з I дослідною групою (рис. 1, д). У лейкограмі крові хворих свиней на 8 день вірогідно $(\mathrm{P}<0,001)$ зростає кількість сегментоядерних нетрофілів, як показано на рисунку 1 (e).

Вивчаючи показники імунобіологічної активності крові здорових та хворих свиней $з$ патологією кінцівок, спостерігається суттєве зрушення у гуморальному та клітинному імунітеті.

Протягом періоду лікування відмічали динаміку зростання компонентів іммунологічної активності в обох дослідних групах (рис. 2, а-е ), зокрема істотна вірогідність ефективності лікування простежувалася у свиней II дослідної групи при застосуванні препарату “Трифузол 1 \%”. Крім того на 8 день дослідження у II дослідній групі збільшилась кількість В-лімфоцитів та популяція Т-клітин: Т-лімфоцити, Т-хелпери і Тсупресори. Відмічалась чітка тенденція збільшення імуноглобулінів класу A, M та G, особливо у хворих свиней II дослідної групи. Зростання концентрації NK-клітин на 8 день лікування, свідчить про зміцнення неспецифічного імунітету і зниженню випадків свиней 3 хворобами пухлин, що реєструвалася протягом періоду дослідження, через генетичну спорідненість (імбридінг). У свиней II дослідної групи активно розвивається імунопатологічна реакція з накопиченням циркулюючих імунних комплексів (ЦІК) і поступово зростає фагоцитарний індекс, активуючи процеси виведення комплексів АГ-АТ.

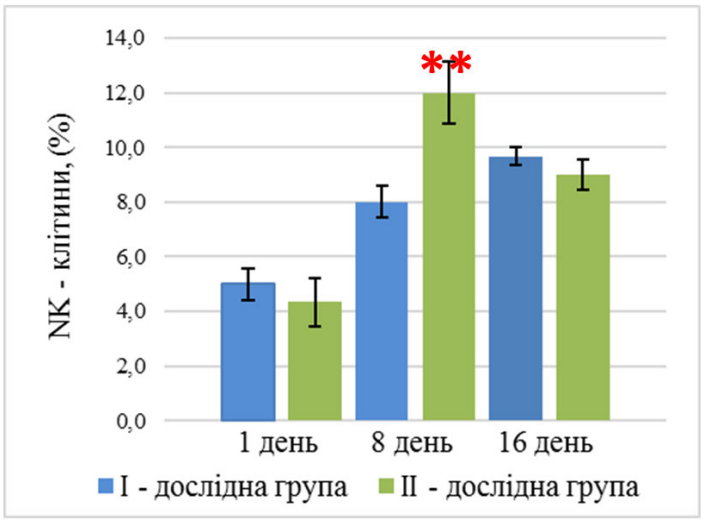

a

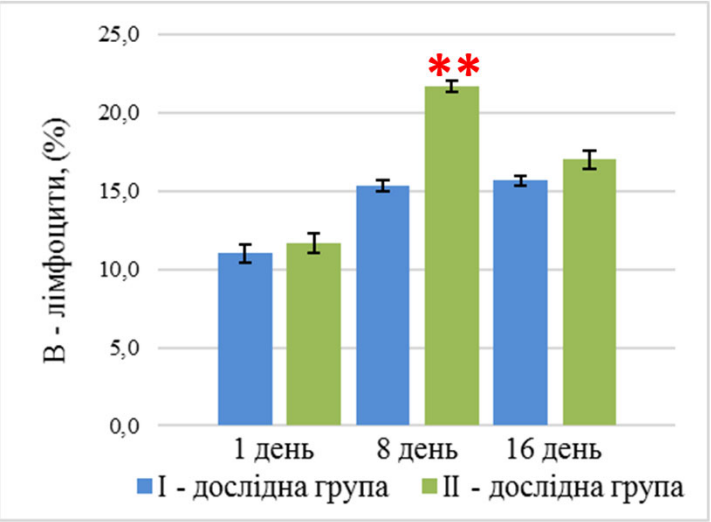

б

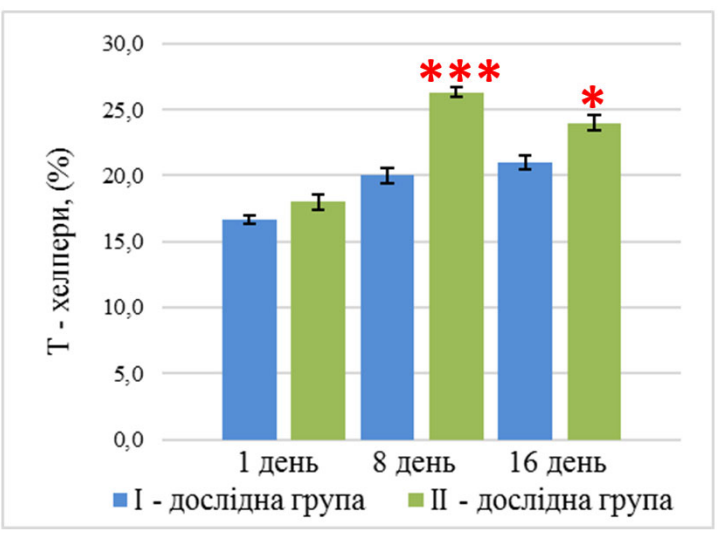

B 


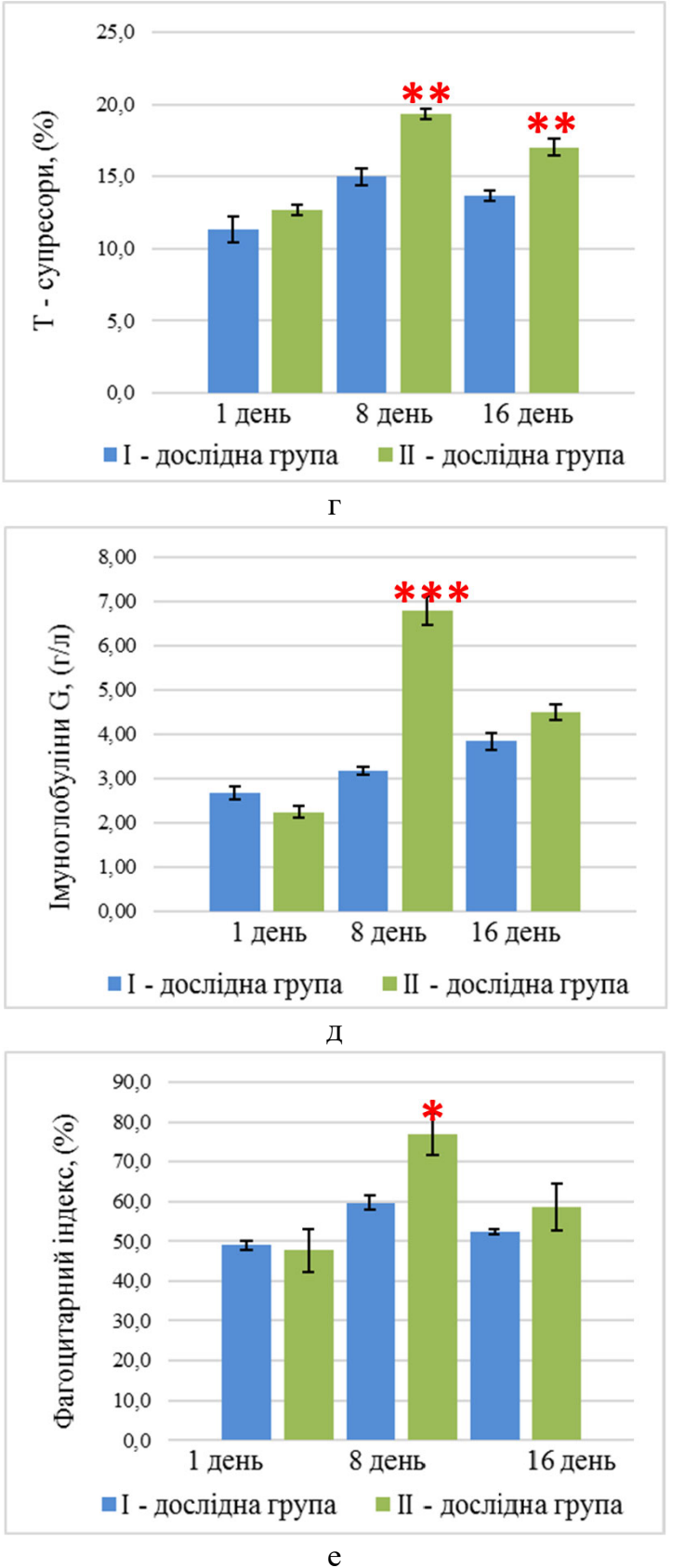

Рис. 2. Результати імунобіологічної активності крові хворих свиней з гнійно-запальними процесами дистального відділу кінцівок в період лікування до повного одужання: а, б - відкрита рана; в, г-абсцес; д - гнійний пододерматит; е - ламініт

Примітка: *_ ${ }_{-}<0,05,{ }^{*}{ }_{-} \mathrm{P}<0,01$ щодо показників днів лікування

\section{Висновки}

Кореляція динаміки змін морфологічних та імунологічних показників крові у дослідних груп свиней, відображає значний терапевтичний ефект лікувальної схеми “експеримент”. Відмічено, що при використанні препарату “Трифузол 1 \%” активується ефекторна та регуляторна функція специфічних компонентів імунної системи (Т- і В-лімфоцити, популяція Тклітин, NK-клітини) за гнійно-запальних процесах дистального відділу кінцівок у свиней. Спостерігалась закономірна тенденція до нормалізації показників крові у хворих свиней порівняно групи контролю протягом всього періоду лікування.

Перспективи подальших досліджень. Для детального вивчення патологій дистального відділу кінцівок у свиней, необхідно доповнити дані результатами клінічних, бактеріологічних і рентгенологічних досліджень.

\section{References}

Cowart, R. P., \& Casteel, S. W. (2002). Muskuloskeletal diseases: foot lesions. An Outline of Swine Diseases: A Handbook, John Wiley \& Sons Inc, New Jersey, 121-122.

Dewey, C. E., Straw, B. E., D’Allaire, S., Mengeling, W. L., \& Taylor, D. J. (2006). Diseases of the nervous and locomotor systems. In: Diseases of Swine. Ames: Blackwell, 861-882.

Garcia, M. C., First, N. L., Ginther, O. J. \& Rutledge, J. J. (1980). Effect of gram-negative bacterial endotoxin, oxytocin and dexamethasone on lactation in sows. Proceedings of the IPVS Congress, 67.

Harris, M. J., Pajor, E. A., Sorrells, A. D., Eicher, S. D., Richert, B. T., \& Marchant-Forde, J. N. (2006). Effects of stall or small group gestation housing on the production, health and behaviour of gilts. Livestock Science, 102(1), 171-179. doi: 10.1016/j.livsci.2005.12.004.

Jensen, T. B., Bonde, M. K., Kongsted, A. G., Toft, N., \& Sorensen, J. T. (2010). The interrelationships between clinical signs and their effect on involuntary culling among pregnant sows in group-housing systems. Animal, 4(11), 1922-1928. doi: 10.1017/S1751731110001102.

Karriker, L. (2013). Identifying, treating and preventing lameness in sows. National Pork Board. Des Moines, IA USA. Retrieved from: https://porkcdn.s3. amazonaws.com/sites/all/files/documents/2013SowHo usingWebinars/Lameness.pdf.

Madsen, D. (2008). A brief overview of selected disease entities diagnosed in swine. American Association of Swine Veterinarians, 2008, 3-6.

Main, D. C. J., Clegg, J., Spatz, A., \& Green, L. E. (2000). Repeatability of a lameness scoring system for finishing pigs. Veterinary Record, 147, 574-576. doi: 10.1136/vr.147.20.574.

Mullan, S., Browne, W. J., Edwards, S. A., Butterworth, A., \& Whay, H. R. (2009). The effect of sampling strategy on the estimated prevalence of welfare outcome measures on finishing pig farms. Applied Animal Behaviour Science, 119(1-2), 39-48. doi: 10.1016/j.applanim.2009.03.008.

Nielsen, E. O., Nielsen, N. C., \& Friis, N. F. (2001). Mycoplasma hyosynoviae arthritis in grower-finisher pigs. Journal of Veterinary Medicine Series aPhysiology Pathology Clinical Medicine, 48(8), 475486. doi: 10.1046/j.1439-0442.2001.00378.x.

Popov, K. O. (2013). Terapiya hromoty u sviney s ispolzovaniem nesteroidnyh sredstv. Perspektivy svinivodstva: teoriya i praktika, 3, 27-30 (in Russian). 
Quinn, A., Calderon Diaz, J. A., \& Boyle, L. (2013). Lameness in Pigs - Moorepark Research Dissemination Day. Pig Developmen Department.

Rowles, C. (2001). Sow Lameness. Journal Swine Health Prod, 9(3), 130-131. https://www.aasv.org/shap/issues/ v9n3/v9n3p130.html.
Smith, B. (1988). Lameness in pigs associated with foot and limb disorders. In Practice, 10, 113-117. doi: 10.1136/inpract.10.3.113.

Wells, G. A. H. (1984). Locomotor disorders of the pig. In Practice, 6(2), 43-53. doi: 10.1136/inpract.6.2.43. 